\title{
Roberto M. Gerstmann y Antonio Quintana Contreras: Estética y fotografía de los indígenas del Norte Grande ${ }^{1}$
}

\section{Roberto M. Gerstmann and Antonio Quintana Contreras: Aesthetic and Photography of the Norte Grande Natives}

\author{
Margarita Alvarado P. \\ Instituto de Estética. Pontificia Universidad Católica de Chile. Santiago \\ malvarap@puc.cl \\ Carla Möller Z. \\ Instituto de Estética, Pontificia Universidad Católica de Chile. Santiago \\ carla.morla@gmail.com
}

Resumen - En el presente trabajo se analiza la obra de dos fotógrafos activos en Chile en los años 30 y 60 del siglo XX. Se reflexiona sobre un corpus de fotografías del Norte Grande chileno, con el fin de definir sus modalidades de producción fotográfica e intentar comprender cómo éstas influyen y/o determinan ciertas formas de representación de las alteridades de los indígenas del desierto y el altiplano (chileno). Se lleva a cabo un análisis comparativo entre la fotografía producida bajo el lente de un esteticista como Roberto M. Gerstmann Henckel, y el registro en imágenes de un documentalista como Antonio Quintana Contreras, para así establecer ciertas diferencias y coincidencias estéticas y formales en las maneras en que se materializa la representación fotográfica de lo Andino.

Palabras claves: fotografía, indígenas andinos, representación.

\begin{abstract}
The following paper analyzes the work of two photographers that worked in Chile between the years 1930 and 1960. It reflects on a corpus of Chilean Norte Grande photographs, aiming to define the patterns of photographic production and trying to understand how these influence and/or determinate certain forms of otherness representation in the Chilean desert and its altiplano. The paper will carry a comparative analysis between photographs produced by the lens of an aesthete such as Roberto M. Gerstmann Henckel and the images registered by a documentalist, such as Antonio Quintana Contreras, so as to establish formal and aesthetical differences and coincidences in the way they materialize photographic representations of the Andes world.
\end{abstract}

Keywords: photography, andean natives, representation.

Este trabajo es producto del Proyecto Fondecyt núm. 1060681 «La representación de la alteridad: Fotografías de los indígenas del Norte Grande (1911-1990)». Responsable: Margarita Alvarado. 
A partir de las primeras décadas del siglo XX la fotografía sufre cambios fundamentales, tanto técnicos como estéticos e históricos. En este sentido será la Primera Guerra Mundial uno de los acontecimientos sociales y políticos que influirá en esos cambios, ya que en sus violentos escenarios se consolidará la mítica figura del fotógrafo/reportero, que ya se venía perfilando desde fines del siglo XIX. Esto será una parte del crisol de lo que más tarde, y con mayor elaboración teórica y práctica, conoceremos como fotografía documental. Conjuntamente con estas tendencias tan fundamentales para la producción fotográfica, seguirán persistiendo otras modalidades de producción visual que se relacionan con concepciones, donde la búsqueda de la belleza o de expresiones estéticas específicas de un paisaje o de un sujeto continuarán siendo parte de importantes motivaciones de diversos autores. Así, las tendencias y géneros fotográficos comienzan a ser el resultado de las convergencias y divergencias de múltiples concepciones, teorías y prácticas fotográficas.

América Latina no es una excepción y en sus repúblicas diversos fotógrafos materializan estas variadas concepciones retratando sujetos y poblaciones indígenas y mestizas, así como paisajes y escenarios rurales y urbanos. Dentro de estos autores destacan en Chile dos de ellos: Roberto M. Gerstmann Henckel y Antonio Quintana Contreras, tanto por su condición de viajeros e itinerantes, como por compartir una clara intencionalidad social y estética documental con la imagen país, además de coincidir cronológicamente en su labor de fotógrafos (láminas 1 y 2).

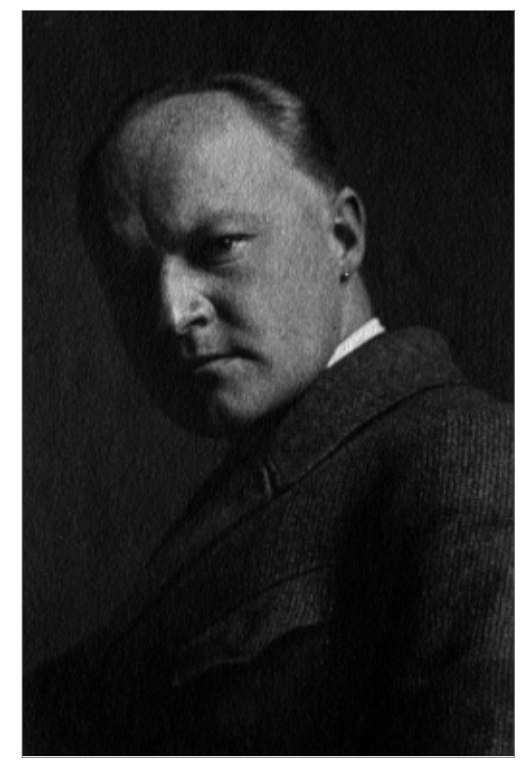

1. Retrato de Roberto M. Gerstmann. Ca. 1930. Autor desconocido. Museo Histórico Nacional, Santiago. 


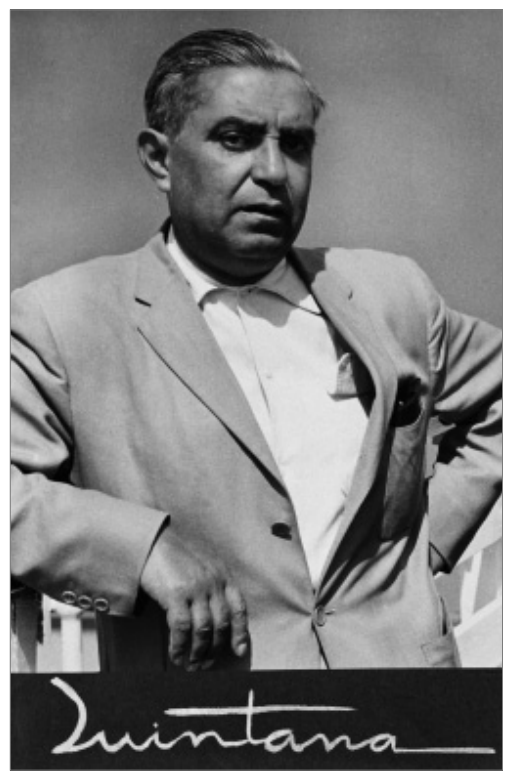

2. Antonio Quintana. Domino Ulloa. Ca. 1940. Unidad de Fotografía, Archivo Central Andrés Bello, Universidad de Chile, Santiago.

El presente trabajo se propone realizar un análisis y reflexión sobre la obra de estos dos fotógrafos, fundamentalmente sobre aquellas imágenes del Norte Grande de Chile, con el fin de llevar a cabo una lectura de sus modalidades de producción fotográfica e intentar comprender cómo estas influyen y/o determinan ciertas formas de representación de las alteridades de los indígenas del desierto y el altiplano chileno. Nuestra intención es comparar la fotografía producida bajo el lente de un esteticista como Gerstmann, con el registro en imágenes de un documentalista como Quintana. Esta comparación permitirá reflexionar acerca de ciertas diferencias y coincidencias estéticas y formales en las maneras en que se materializa la representación fotográfica de lo Andino².

\section{GERSTMANN Y QUINTANA EN EL ESCENARIO FOTOGRÁFICO LATINOAMERICANO}

Antes de adentrarnos en el análisis de la obra de estos dos fotógrafos y de llevar a cabo los ejercicios comparativos planteados para su producción, para contextualizar su trabajo, veamos un panorama de la práctica fotográfica en América Latina, sobre todo en relación a las estéticas y modalidades de representación de la fotografía en estos territorios.

2 El término lo Andino se utiliza aquí para definir las poblaciones y territorios de la zona de los Andes que comprende el norte de Chile, el sur de Bolivia y Perú y el norte de Argentina. Esta zona comprende gran cantidad de etnias y culturas diferentes. No estamos utilizando este concepto en la complejidad teórica y metodológica que se utiliza en relación a la antropología, la arqueología y la etnohistoria. 
Un aspecto directamente relacionado con la producción de Gerstmann y Quintana es que el escenario visual latinoamericano se construye, desde sus inicios, mediante un proceso de identidad fotográfica que podríamos definir como exotizante, tanto por sus territorios y naturaleza, como por su población indígena de una gran diversidad de etnias y pueblos. A pesar de que la pintura y el grabado individualizaron parajes y poblaciones, es la fotografía la que alcanza el rigor realista que inicia el proceso de convertir a Latinoamérica en un territorio deseado, rigor que se traspasa a los acontecimientos sociales y políticos en la región a lo largo de todo el siglo XX.

Para las tempranas épocas del siglo XIX y comienzos del siglo XX surgen fotógrafos, viajeros, expedicionarios y científicos que recorren los más diversos y lejanos territorios registrando estas nuevas realidades que encontraban a su paso, bajo las modalidades estéticas propias del retrato de estudio de la época, donde la pose y la escenificación que acompañaban al sujeto fotografiado eran fundamentales (Alvarado et al., 2001). Conjuntamente, diversos estudiosos realizan tomas que se pueden enmarcar bajo la tradición de la llamada fotografía antropométrica, sobre todo en Chile y Argentina, práctica fotográfica muy acorde a los proyectos científicos que buscaban registrar y clasificar aspectos raciales de las poblaciones nativas americanas (Maturana, 2007).

Como en otras partes del mundo, en América en los años inmediatos al fin de la Primera Guerra Mundial, las modalidades y estéticas de la práctica documental se determinan a partir de las nuevas condiciones técnicas y de una visión crítica de la realidad, lo que definió también la cualidad de sentido de esta fotografía. La fuerza del referente fue tal, que los fotógrafos se hicieron parte directa de la transmisión de éste, a través de la imagen fotográfica, quedando instaurada la mítica definición de la fotografía latinoamericana como una fotografía documental por excelencia. A partir de los años ochenta del siglo XX fue posible entender, sin embargo, que la práctica fotográfica en las regiones de Latinoamérica siempre tuvo subyacente alguna noción de irrealidad, fantasía o ambigüedad.

Verse y ser visto es una buena manera de describir sintéticamente la cualidad que transversalmente tiene la fotografía y da un sentido universal a la imagen, pero que cobra un sentido profundo y particular en Latinoamérica, dada la histórica desinformación que caracteriza a esta región frente al mundo europeo. No es menor el hecho de que Iván de la Nuez (2003-2004), crítico y teórico, sitúe como un hito que marca la entrada de la fotografía latinoamericana en la era de la imagen, el retrato de Che Guevara tomado en La Habana en 1960 por Alberto Díaz (Korda), difundido después de su muerte en Bolivia.

Para la época en que Gerstmann y Quintana comienzan sus primeras incursiones como fotógrafos, en Latinoamérica, entre los años 20 y 30, se intensifica la expresión local de la cual ellos forman parte. Los autores de estos años comprenden las posibilidades de representación e independencia del medio fotográfico y se van individualizando por estéticas,temáticas y estilos. Entre 1930 y 1960 el desarrollo de la fotografía en Latinoamérica también transita hacia las vanguardias. Los fotógrafos se abren cada vez más a influencias europeas y americanas buscando nuevos cauces y planteamientos intelectuales, con una notoria participación de la creatividad y punto de vista personal del autor. Sin abandonar los referentes locales, la identidad y la realidad circundante, miran desde otros ángulos y otras luces, es una fotografía más analítica y consciente de sí misma. La fotografía de autor toma forma de obra digna de galerías y museos con influencias del expresionismo, la Bauhaus y el surrealismo, entre otros. 
En este contexto de la producción fotográfica latinoamericana se enmarca el trabajo de Roberto Gerstmann y Antonio Quintana, quienes desde perspectivas y estrategias visuales diferentes, fotografían a los habitantes del norte de Chile, proyectando hacia nosotros sus particulares miradas. Para abordar una comparación de esas miradas veamos ahora algunos aspectos generales de su vida y su trabajo.

\section{ROBERTO GERSTMANN, UNA MIRADA ITINERANTE}

Este fotógrafo nació en 1896, probablemente en la ciudad de San Petersburgo, en Rusia. Durante su juventud se dedicó, además de sus estudios como ingeniero, a la fotografía como aficionado, pero no se conocen hasta ahora, imágenes de esta época de su vida. Decidido a buscar otros horizontes, llega a Chile en 1924 para desempeñarse como ingeniero electro-técnico, profesión que le permitirá viajar por varios países de América del Sur y muchas veces solventar su trabajo como fotógrafo. Como lo testimonia su inmensa obra que alcanza a cerca de diez mil imágenes recopiladas en archivos nacionales y extranjeros, viaja por todo Chile, incluida la Antártica, continuando luego por Bolivia por casi tres años. A su regreso se instala en nuestro país de manera definitiva, recorriendo esporádicamente otros países como Colombia y Ecuador. Producto de estos extensos periplos produce tres libros, editados por Braun \& Cía. Èditeurs de París, que fueron comercializados con la clara idea de difundir y propagar las cualidades geográficas, económicas y estéticas de Chile, Bolivia y Colombia (Gertsmann 1928, 1932, 1951). Apoyado por importantes instituciones públicas y privadas, realiza trabajos por encargo y se dedica a registrar cuadro a cuadro todo Chile de norte a sur, incluidos sus habitantes y poblaciones nativas (Alvarado, Matthews y Möller, 2008).

Gerstmann desarrolla esta extensa obra fotográfica dentro de patrones estéticos específicos y aplica sus conocimientos técnicos y formales a la realización de una imagen equilibrada y armónica con notable manejo de la luz y la composición. Transforma la geografía que recorre en el principal sujeto de sus imágenes, cuestión que se refleja en la gran cantidad de tomas de paisajes fotografiados con las más diversas técnicas y formatos. En esta búsqueda, sus viajes por diversos países latinoamericanos de la región andina se constituyen en un suceso fotográfico de proyección documental, pero sobre todo estético. La importancia de su obra es tal, que se puede decir que vuelve a instalar para Chile, de manera persistente, la tradición del género paisajístico en fotografía.

Su permanente itinerancia, esa mirada siempre en tránsito y movimiento sobre el paisaje se puede reconstruir a través de su obra conservada, mayoritariamente, en diversos archivos fotográficos de Museos e instituciones de nuestro país ${ }^{3}$. Su actitud de legado y el valor documental de sus imágenes se percibe claramente al observar con qué tenacidad y sistematización él mismo ordenó y clasificó en cajas, álbumes y listados sus materiales. Especial interés, en cuanto a la constitución de un relato visual desde su particular perspectiva, presentan veintitrés álbumes monográficos empastados que contienen fotografías de Chile, Bolivia, Isla de Pascua, Perú, Ecuador y la Antártica. Esta extensa obra

La obra de este fotógrafo está conservada principalmente en los Archivos Fotográficos del Museo Histórico Nacional, del Museo Chileno de Arte Precolombino en Santiago y en el Archivo Roberto Gerstmann de la Biblioteca de la Universidad Católica de Antofagasta. 
revela no sólo su manera de situarse frente a un paisaje constituido en sujeto y de retratar diversos habitantes de lejanos y exóticos lugares, si no que fundamentalmente, nos entrega la manera en que Gerstmann quiere que nosotros observemos y participemos de su itinerancia visual sobre estos espacios americanos.

En su obra referida a Chile, los paisajes, silenciosos, imperturbables e inequívocamente bellos realizados de norte a sur, en lo fundamental no difieren de los registrados en otros países latinoamericanos. El desierto del Norte Grande, los valles de Chile Central, las selvas y estepas del extremo sur, son registrados considerando especialmente las particularidades de cada uno de estos espacios geográficos desde la luminosidad de sus cielos, la topografía de sus territorios, sus especies vegetales y animales y por supuesto sus habitantes. Para el norte de Chile sus modalidades de representación fotográfica incluyen, de manera muy especial, las poblaciones indígenas, retratándolas como parte casi constitutiva de estos extensos y aparentemente inhóspitos espacios. Bajo esta mirada fotográfica del viajero, que transita por el desierto y el altiplano, los habitantes de estos pueblos aparecen retratados, más que en sus particularidades étnicas y culturales, formando parte de este paisaje, casi invisibilizados por grandes planos generales y encuadres abiertos. El interés fotográfico de Roberto Gerstmann se posiciona en las distancias, los horizontes y los elementos naturales a modo de referentes de identidad y como una significativa visión de la alteridad, tanto en el paisaje natural como de los paisajes intervenidos por la actividad productiva.

El autor combina dos tradiciones visuales, por un lado una visión más pintoresca y romántica, que se expresa en una especie de purismo fotográfico que busca una imagen claramente definida y fiel a las luces y las sombras y, por otro, una mirada siempre itinerante y exploratoria que hace del paisaje su principal sujeto fotográfico. Materializa así una estética depurada y bella, haciendo que lo fotográfico trascienda definitivamente hacia la creación artística, donde nuestros ojos, al desplazarse por el paisaje encuadrado se afirmen en una composición impecable. De esta forma, no hay nada que perturbe nuestra mirada. Roberto Gerstmann nos enseña a ver el paisaje americano a través de su propia intuición y su razonamiento.

Este fotógrafo muere en Santiago en 1964, en su casa de avenida Colón, que durante muchos años fue su domicilio y su laboratorio, en la más rigurosa y austera soledad, tal cual fue su larga vida itinerante y viajera.

\section{ANTONIO QUINTANA, UNA MIRADA SOCIAL}

Este fotógrafo, a diferencia de Gerstmann, nació en Santiago en 1904 y su formación se relaciona más con las ciencias y la enseñanza. Durante los años 20 del siglo XX, estudia Pedagogía en Química y Física en la Universidad de Chile de Santiago, dedicándose luego a la docencia como profesor primario hasta 1930, en las ciudades de Talca y Puerto Montt. Esta formación como educador tendrá una importancia fundamental en su actividad como fotógrafo, ya que en 1940 implementa y dicta por primera vez en nuestro país la cátedra de Fotografía Artística, Panorámica, Industrial y de Reproducciones y Retoque Fotográfico, en la Escuela Nacional de Artes Gráficas, que implicará, nada menos, la institucionalización de la enseñanza de la fotografía a nivel universitario. 
Pero lo que resultará aún más trascendental, en cuanto a su trabajo y su trayectoria fotográfica, será su ingreso al Partido Comunista de Chile en el año 1919, ya que esta mirada de fuerte contenido social será la impronta que caracterizará su producción visual, haciéndose presente en toda su obra. Esta consciencia social se instalará como referente fundamental de sus representaciones fotográficas, transformándolo en uno de los precursores de la fotografía documental social en Chile.

$\mathrm{Su}$ inicio como fotógrafo es a partir de los años 30, probablemente impulsado por la expulsión del magisterio de la que es víctima bajo el gobierno de Carlos Ibáñez del Campo (1927-1931). Por esta época estudia Filosofía e Historia del arte y desarrolla su actividad, principalmente allegado a la Universidad de Chile, en la Facultad de Arte y Arquitectura de dicha institución. Si bien su formación como fotógrafo es totalmente autodidacta, sus estudios en el ámbito de la química le ayudan de sobremanera a explorar en los aspectos técnicos de reproducción y laboratorio, adquiriendo rápidamente una independencia estilística y creativa. Esta impronta tan particular de su estética fotográfica se verá reflejada en sus obras presentadas en los Salones Oficiales de Bellas Artes y Fotografía, realizados entre los años 1935 y 1939. Esta actividad expositora convocaba a la mayoría de los fotógrafos que se encontraban trabajando en nuestro país, incentivando la realización de su obra fotográfica y legitimando este tipo de creación en el ámbito de la Bellas Artes. No deja de ser notable comprobar que en el Salón de 1934, justo un año antes que Quintana presentara por primera vez una obra, Roberto Gerstmann ya participa con un trabajo, el registro en 1942 del mural realizado en la Escuela México de la ciudad de Chillán, por David Alfaro Siqueiros (1896-1974), quien plasma en su obra aspectos de la historia de nuestras repúblicas americanas, marca su trabajo como fotógrafo documentalista. El desafío de registrar el trabajo del pintor y el desarrollo de la obra lo enfrentan a las problemáticas y estéticas de la fotografía documental.

Contrariamente a Gerstmann, Quintana fue un fotógrafo obligado a itinerar a causa de las situaciones políticas que se producen en Chile bajo la presidencia de Gabriel González Videla (1946-1952), quien declara al Partido Comunista fuera de la ley. Durante su exilio, entre los años 1948 y 1954, recorre Argentina, Uruguay y Brasil, lo que consolidará definitivamente su mirada social contenida en sus fotografías, al tener la oportunidad de conocer otras realidades latinoamericanas. A su regreso a Chile retoma sus actividades educacionales haciéndose cargo de la cátedra de Fotografía de la Escuela de Periodismo de la Universidad de Chile y desempeñándose como ayudante de laboratorio del Archivo Central de Fotografía y Cinematografía de la misma Universidad, lo que le permitirá seguir combinando su trabajo como fotógrafo, con la experimentación de técnicas y soportes.

La obra de este fotógrafo nos revela su concentración en su tiempo, un tiempo real, concreto y en las visiones extraordinarias del pueblo chileno como una de sus principales características. A través de las más variadas escenas cotidianas, con las prisas y trabajos de todos los días, Quintana compone y registra al hombre y a la mujer como protagonistas, siempre referidos a sus quehaceres de trabajadores, campesinos, pescadores, artesanos, lo que le impone postura, seño y actitud. El hombre en su contexto social dignificado en el trabajo, aún cuando el encuadre muchas veces se ciña al retrato. Su extensa y prolífera obra, materializada en miles de negativos blanco y negro, positivos de diversos formatos, incluso de grandes formatos con los que experimentó de forma pionera, se 
resguarda, principalmente, en la Unidad de Fotografía, Archivo Central Andrés Bello, Universidad de Chile, Santiago. ${ }^{4}$

Sin lugar a dudas su proyecto más emblemático y conocido es la gran exposición titulada Rostro de Chile, inaugurada el año 1960 en la Casa Central de la Universidad de Chile. Si bien el proyecto fue dirigido por el fotógrafo Roberto Montandón, quien en ese momento era el jefe del Laboratorio Fotográfico de esta Universidad, el gran gestor y realizador fue el propio Quintana. Como la exposición fue ideada con motivo de la conmemoración de los 150 años de la independencia de nuestro país, su objetivo fundamental era configurar un retrato visual de nuestra nación, dando cuenta, a través de la fotografía, de las realidades geográficas y sociales de nuestros habitantes. Los trabajos se iniciaron cuando Quintana presentó el proyecto al entonces Secretario general de la Universidad de Chile, Álvaro Bunster, en 1958. A partir de ese momento un equipo de fotógrafos encabezados por Montandón, y en el cual participaron además Domingo Ulloa, Mario Guillard y Fernando Ballet, entre otros, se dedicaron a viajar por todo Chile, lo cual le imprimió a este proyecto una diversidad de miradas y propuestas fotográficas (Moreno y Fresard, 2006) . Como el gran referente de esta muestra, esta la exposición The Family of Man, realizada en el Museo de Arte Moderno de Nueva York en el año de $1955^{6}$. Guardando las diferencias temporales y de contexto, es posible plantear que ambas muestran buscaban establecer visualmente aquellas cualidades sociales y humanas que hermanaban más allá de las fronteras y las nacionalidades, buscando diluir las diferencias raciales y sociales que habían sido tan exacerbadas en el período de la guerra y que continuaban vigentes en medio del comienzo de la Guerra Fría. De esta manera, la fotografía, y sobre todo la fotografía en su modalidad documental, se hacía parte indiscutible de los procesos políticos, históricos y sociales, ya no solo nacionales si no a nivel continental y mundial.

Las fotografías que Quintana realiza para este proyecto muestran su capacidad de configurar retratos y vistas de paisajes de encuadres llenos, que revelan, no solo su acabado conocimiento como fotógrafo, sino fundamentalmente su sensibilidad y clara percepción de los temas sociales y humanos. Estas modalidades de producción fotográfica quedan en evidencia en su trabajo en el norte de Chile, donde se aprecian los recorridos realizados por los pueblos del altiplano, el desierto y las ciudades costeras con sus industrias y puertos.

La mirada de este creador es evidentemente documental-social, una mirada que escudriña todos los ángulos de un lugar y un acontecimiento, y que se puede apreciar claramente al observar su obra en su conjunto. Son claras evidencias de este género fotográfico las secuencias que muestran el recorrido de su lente desde los grandes espacios fotografiados, con tomas panorámicas o de planos generales sobre paisajes del desierto y las quebradas, pueblos y valles de las tierras altas y las zonas altiplánicas, hasta las particularidades de un rincón o detalle de ese mismo pueblo o lugar, registrado con planos medios y a veces primeros planos. Esta manera de acercarse a lo que desea o busca

$4 \quad$ La obra de Antonio Quintana alcanza a cerca de 7000 fotografías, principalmente conservadas en este Archivo.

5 Cabe señalar que esta muestra, después de su exhibición en Chile, viajó por varios países de América, Estados Unidos de América y Japón. En este último país fue presentada en la Feria de Osaka en 1969.

6 La exposición The Family of Man, organizada por Edward Steichen, se realizó como una necesidad de mostrar y resumir la fotografía Life, que hasta ese momento, diez años después de la Segunda Guerra Mundial, contaba con una colección casi ilimitada de imágenes (Tausk, 1978). 
documentar también se puede apreciar en una gran cantidad de imágenes de rituales y fiestas religiosas en diversas comunidades del norte de Chile.

Quintana muere en Santiago en 1972, desapareciendo así uno de los maestros y formadores de numerosas generaciones de fotógrafos en nuestro país, quien siempre incentivó a sus discípulos en la búsqueda de nuevas estéticas y en la investigación de la técnica, aspectos que siempre consideró como parte fundamental del trabajo fotográfico.

\section{REPRESENTACIÓN, PRODUCCIÓN FOTOGRÁFICA Y ALTERIDADES INDÍGENAS DEL DESIERTO Y EL ALTIPLANO (CHILENO)}

Para indagar en las modalidades visuales utilizadas por Roberto Gerstmann y Antonio Quintana en la producción de las fotografías de los indígenas del norte de Chile y llevar a cabo un análisis comparativo de las estéticas visuales contenidas en ellas, es necesario puntualizar, operativamente, algunos conceptos y estrategias en cuanto a la fotografía como medio expresivo y sus particularidades como imagen.

Definimos la fotografía como un sistema convencionalizado de representación visual que posee particularidades determinadas (Batchen, 2004). En el caso específico de los corpus fotográficos que estamos analizando en este trabajo, al hablar de representación, nos estamos refiriendo a ese presente etnográfico "atemporal» que apela a nuestro imaginario cuando los observamos, considerando que con esta tecnología, el fotógrafo enmarca arbitrariamente un suceso o personaje, en un espacio (Sontag, 1996). De esta manera, más allá de los cuestionamientos de la fotografía como mimesis de la realidad, la imagen fotográfica se constituye en representación en la medida que trae al presente un suceso, un paisaje o un personaje determinado. Este «re-presentar» (volver a presentar) en el caso de la fotografía de estas alteridades andinas - muchas veces llamada también «fotografía etnográfica»— resulta particularmente importante si consideramos que estas fotografías traen al presente retratos y costumbres de pueblos que, producto de la influencia de ciertos procesos modernizadores, han cambiado sustancialmente sus prácticas culturales, como indumentarias, rituales y estrategias de sobrevivencia, sobre todo, en las últimas décadas del siglo XX y comienzos del siglo XXI. ${ }^{7}$

De acuerdo a este concepto básico y operativo de representación, nos posicionamos desde la producción de la imagen fotográfica para trabajar las problemáticas planteadas, ya que de esta manera nos podemos adentrar en las particularidades específicas de la fotografía (Szarkoski, 1966). En este sentido, entendemos por producción el proceso mediante el cual se construye la imagen fotográfica, de acuerdo a sus particularidades estéticas y técnicas, explorando en la mirada de los dos autores elegidos, bajo una estrategia que apunta a la individualización y análisis de los «conceptos» que son "peculiares de la fotografía» (Batchen, 2004: 22).

Siguiendo a Brisset (1999: 11-5), la fotografía etnográfica se define como aquella imagen que obtenida por diversos emisores - antropólogos, etnógrafos, viajeros, fotógrafos, misioneros, etc.- es susceptible de ser empleada como fuente de datos en investigaciones antropológicas. Uno de los aspectos más significativos de esta utilización es el reconocimiento de su valor documental y su equiparación con textos escritos al momento de obtener críticamente información reveladora de ciertos aspectos culturales. 
Posicionarse desde la producción implica dejar en las sombras problemáticas tan importantes como los modos en que nuestra sociedad se ha apropiado y manipulado las llamadas fotografías etnográficas, o también cómo esta sociedad dominante ha construido sus propias identidades visuales en oposición a las alteridades indígenas representadas en estas fotografías, o por último, la reflexión acerca de cómo estas imágenes han sido utilizadas en distintos discursos científicos, artísticos o legislativos, para afirmar y reafirmar ciertos estereotipos del «otro», construidos visualmente desde las sociedades dominantes (Alvarado et alt, 2001; Masotta, 2007; Poole, 2000). Esta decisión se fundamenta en que dichas problemáticas se relacionan más con los contextos de circulación y los diversos sistemas discursivos donde las imágenes fotográficas están siendo actualizadas y nuestro interés se focaliza en las modalidades de producción fotográfica de Roberto Gerstmann y Antonio Quintana ${ }^{8}$.

Si como decíamos, la imagen fotográfica es un sistema convencionalizado de representación visual, sin duda, cada imagen se materializa de acuerdo a convenciones formales que definen las manipulaciones legítimas y distorsiones permisibles a las que puede ser sometida en su producción (Tagg, 1988). Como representación se constituye entonces en una construcción arbitraria, realizada por un fotógrafo, quien opera de acuerdo a la utilización de ciertos dispositivos y procedimientos visuales, los cuales se manifiestan y materializan en el acto fotográfico (Burgin, 2004; Dubois, 1986).

La configuración estética de una fotografía se materializa en la utilización de diversos dispositivos visuales 9 . Para el ejercicio de comparación que buscamos realizar de la producción de estos dos autores nos focalizaremos en el encuadre, con tres de sus elementos básicos: plano, foco y ángulo de toma, por considerar que constituyen los elementos formales que mejor revelan la mirada del fotógrafo como operador ${ }^{10}$. Respecto de los procedimientos visuales, el fotógrafo como operador instala al sujeto retratado en un escenario, llevando a cabo ciertas acciones que le permiten organizarlos antes de disparar el obturador ${ }^{11}$.

8 Bajo este criterio tampoco hemos considerado la relación de poder que se establece entre el productor de la imagen y el sujeto fotografiado, ya que nuestro interés está centrado en las estéticas comprometidas en las modalidades de representación fotográfica-visual de los indígenas del norte de Chile. Sobre este tema, fundamental resulta el trabajo de Dánae Fiore (2007).

9 Se utiliza el concepto de dispositivo en cuanto a su acepción de mecanismo, es decir, un conjunto de elementos conceptuales y materiales que maneja el fotógrafo, como operador, engarzados de tal forma que generan una imagen con una estética fotográfica específica.

10 El concepto de «encuadre» comprende todo lo que se encuentra presente en la imagen. Determina el «cuadro» de la fotografía, a partir del cual se ordena la composición plástica de la imagen. Se refiere a los límites de lo fotografiado determinados por la posición de la cámara y su distancia con el sujeto. En relación al encuadre se pueden distinguir diversos «planos»; para nuestro análisis hemos consideraremos tres: (a) "primer plano", cuando existen uno o más sujetos retratados desde el pecho hacia arriba; (b) "plano medio", encuadre que muestra a el o los sujetos desde la rodilla hasta la cabeza, y se puede apreciar parcialmente el contexto, y (c) «plano general», donde el o los sujetos aparecen de cuerpo entero y muchas veces se puede apreciar el contexto general. El concepto «foco» comprende la nitidez selectiva que aplica el operador según la importancia que le confiere a su sujeto fotográfico. El concepto «ángulo de toma» se define como la posición de la cámara con respecto al sujeto fotografiado. Se pueden distinguir dos posiciones fundamentales: (a) A nivel de los ojos, cámara y sujeto se encuentran en relación horizontal, es decir lo fotografiado se presenta posicionado directamente frente a la cámara, y (b) picado/contrapicado, cuando la cámara mira desde una angulación mayor a $45^{\circ}$, tanto desde arriba como desde abajo, respecto de lo fotografiado. Para mayor información véase Cordero, 2001.

11 Se define el concepto de procedimiento en su acepción de ordenar, de organizar algo en el desarrollo de una actividad, es decir, como el conjunto de acciones y pasos que sigue un fotógrafo para ordenar un sujeto y un escenario antes de disparar el obturador. 
De acuerdo a estos conceptos y definiciones sobre la fotografía, el fotógrafo como operador y los dispositivos y procedimientos visuales, utilizados en la producción de su imagen y las modalidades de representación que están presentes, analicemos ahora la producción de Gerstmann y Quintana.

\section{ESTÉTICAS Y MODALIDADES DE REPRESENTACIÓN DEL PAISAJE Y LOS HABITANTES DEL DESIERTO Y DEL ALTIPLANO (CHILENO) EN DOS MIRADAS}

Para llevar a cabo nuestro análisis hemos tomado como referente parte de los corpus fotográficos de Roberto Gerstmann y Antonio Quintana que corresponden a tres modalidades de producción fotográfica del territorio del Norte Grande de Chile. La identificación de cada corpus está dada por la presencia/ausencia del indígena andino que se puede observar como sujeto que participa de las imágenes fotográficas y la estética particular que cada fotógrafo asume, según sus intereses personales y profesionales. Los tres corpus fotográficos o categorías visuales definidas para cada autor son identificados como: "paisaje social y festividad ritual», «sujeto dentro del paisaje» y "paisaje sin sujeto».

En el corpus de «paisaje social y festividad ritual» se incluyen aquellas fotografías en que el sujeto andino se encuentra realizando una acción dentro de un contexto ritual, específicamente lo que se conoce como una festividad religiosa, evento muy común en las comunidades y pueblos del norte de Chile que se celebra sobre todo en relación a expresiones de la religión católica. En estas imágenes el sujeto aparece concentrado en un evento social-religioso particular, que involucra a toda la comunidad y que se realiza bajo la modalidad ritual, que incluye cofradías de danzantes con indumentarias muy variadas, procesiones con la Virgen María y diversos Santos o Santas y una masiva concurrencia provenientes de diversos lugares. Fotográficamente la festividad se constituye en el referente principal, por lo tanto su registro corresponde a una cobertura documental.

Para el corpus denominado "sujeto dentro del paisaje» se han considerado aquellas fotografías donde el sujeto aparece en la imagen, pero como un elemento más del paisaje, sin ningún protagonismo estético o documental. Desde esta perspectiva el paisaje se constituye en un escenario geográfico específico y el sujeto andino pasa a ser parte de la composición, asumiendo un rol claramente representativo de una situación social o étnica que completa el contexto en el cual se encuentra inserto. En este sentido, se vincula con lo que comúnmente se denomina fotografía social.

Por último, en la categoría de "paisaje sin sujeto» se incluyen aquellas imágenes en las que el paisaje pasa a ser el sujeto, y su protagonismo visual es destacado por una representación que se concentra en sus características estéticas y geográficas. Para el caso del Norte Grande de Chile, donde los inmensos espacios inhabitados del desierto o las extensiones del altiplano interrumpidas ocasionalmente por quebradas o ríos, no extraña que este paisaje sea retratado en su soledad, conformada por una naturaleza no sometida a la mano del hombre. Este tipo de imágenes es lo que comúnmente se adscribe al género del paisaje. 


\section{ESTÉTICA, PAISAJE SOCIAL Y FESTIVIDAD RITUAL EN LA FOTOGRAFÍA DE GERSTMANN Y QUINTANA}

Para una comparación del corpus «paisaje social y festividad ritual» entre las modalidades de representación del indígena del Norte Grande de estos dos autores, hemos tomado como referente las imágenes realizadas, por un lado, por Roberto Gerstmann en la celebración a la Virgen del Carmen, en el pueblo de Conchi Viejo (Región de Antofagasta, Chile) que se lleva a cabo el 16 de julio de cada año; y por otro, por Antonio Quintana en la celebración a la Virgen del Carmen que se realiza en el pueblo de La Tirana, Comuna de Pozo Almonte (Región de Tarapacá), entre el 12 y 18 de julio de cada año. Esta celebración también se conoce como Fiesta de La Tirana y es el evento de estas características más importante del norte de Chile. Las imágenes que analizaremos fueron realizadas en dos eventos que corresponden a fiestas religiosas con un mismo origen ritual e iconográfico: la Virgen del Carmen, en dos pueblos del norte de Chile ${ }^{12}$. En el período en que estas imágenes fueron realizadas, alrededor de las décadas del treinta y cincuenta, la práctica de la fotografía documental estaba evidentemente vinculada a la búsqueda y consolidación de una imagen "país», donde se intentaba generar una visión que abarcara todo nuestro territorio, considerando aspectos sociales, económicos y sobre todo culturales. En este contexto, la cobertura documental de manifestaciones como estos eventos rituales implicaba producir imágenes que permitieran dar a conocer a la sociedad en general, tradiciones y costumbres que ocurrían lejos de las grandes ciudades, pero que indudablemente formaban o debían formar parte de nuestra identidad nacional.

El trabajo de Roberto Gerstmann no se define en la cobertura total y ordenada de los acontecimientos. Desde los dispositivos visuales se concentra en encuadres cerrados con los que delimita los planos medios y los primeros planos, haciendo del retrato grupal su principal manifestación (lámina 3). Los encuadres abiertos los reserva para la aproximación y distanciamiento de los hechos, entra y sale o viceversa —no podemos definirlo porque no tenemos el orden correlativo en que fueron realizadas las tomas- fijando las características generales del evento siempre con relación a los participantes, en su contexto territorial (láminas 4 y 5). Desde los procedimientos visuales, a través de la pose, Gerstmann registra la festividad religiosa, particularizando e identificando los sujetos dentro de los encuadres (lámina 6). Así tenemos por ejemplo, los músicos de lejos y de cerca, la llegada de gente de otros pueblos a Conchi Viejo tomada desde lo alto, calles del pueblo con gran cantidad de personas y diversas tomas de la fachada de la Iglesia, variando en el formato de lo vertical a lo horizontal, moviéndose de lo general al detalle (lámina 7). Por último, dentro de esta festividad religiosa, las manifestaciones asociadas a las ferias en sus connotaciones más lúdicas y alegóricas, incluyen la producción de fotógrafos itinerantes con su máquina de cajón, que despliegan una parafernalia de telones y escenografías de artificios. Gerstmann es cautivado con esta situación en que los asistentes a este evento religioso resultan seducidos por la posibilidad de ser otros, en lejanos y exóticos lugares, representados por el telón. No deja de ser paradójico que estos habitantes del desierto y el altiplano "naveguen» en un bote en medio del «descubrimiento de América», situación que Gerstmann no puede resistir fotografiar con su propia cámara (lámina 8).

12 Estos dos pueblos nortinos presentan características topográficas y geográficas muy diferentes. Conchi Viejo esta ubicado en la zona llamada Tierras Altas del Loa y La Tirana se encuentran en medio del desierto, en la llamada Pampa del Tamarugal. 


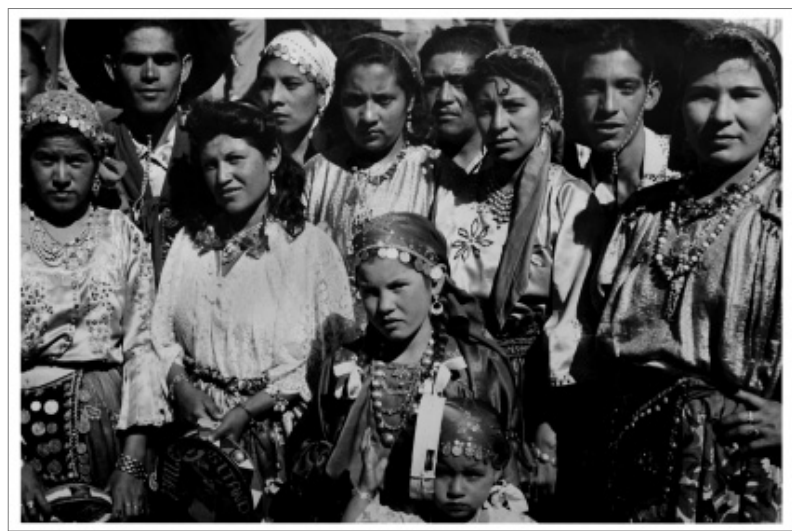

3. Conchi Viejo, Región de Antofagasta, Chile. Roberto M. Gerstmann. Ca. 1940. Archivo Roberto Gerstmann, Biblioteca Universidad Católica del Norte, Antofagasta.

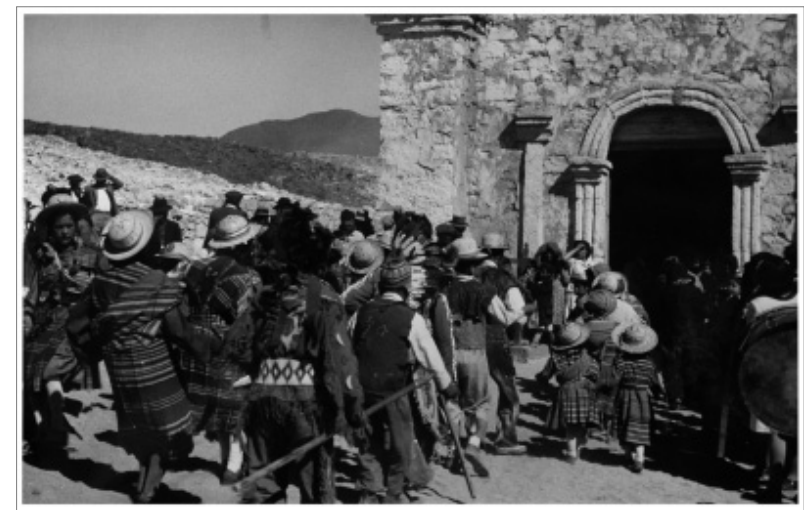

4. Conchi Viejo, Región de Antofagasta, Chile. Roberto M. Gerstmann. Ca. 1940. Archivo Roberto Gerstmann, Biblioteca Universidad Católica del Norte, Antofagasta.

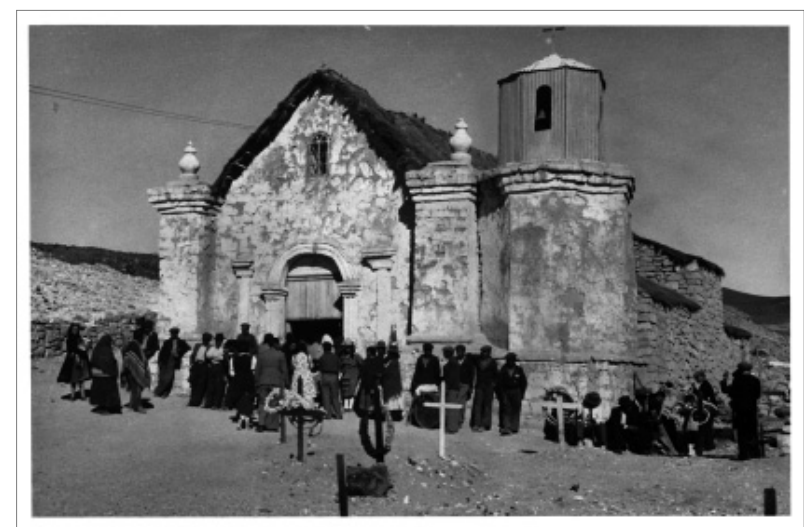

5. Conchi Viejo, Región de Antofagasta, Chile. Roberto M. Gerstmann. Ca. 1940. Archivo Roberto Gerstmann, Biblioteca Universidad Católica del Norte, Antofagasta. 
I 64

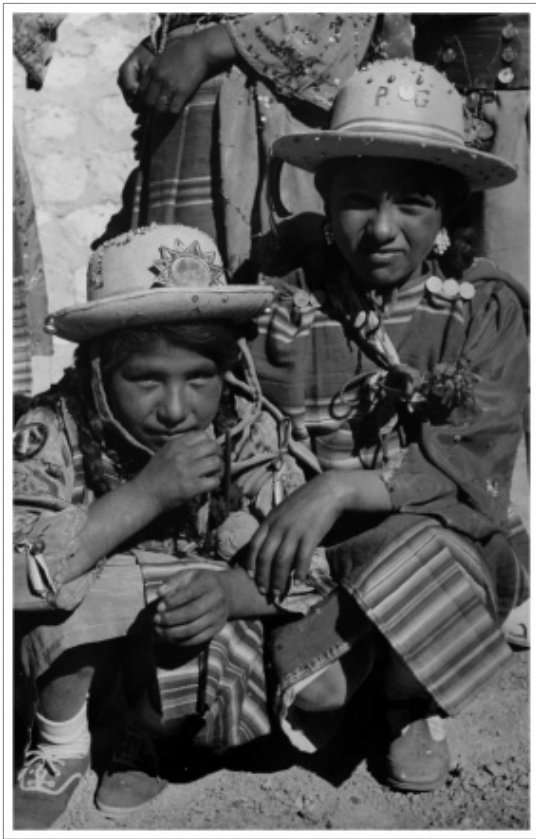

6. Conchi Viejo, Región de Antofagasta, Chile. Roberto M. Gerstmann. Ca. 1940. Archivo Roberto Gerstmann, Biblioteca Universidad Católica del Norte, Antofagasta.

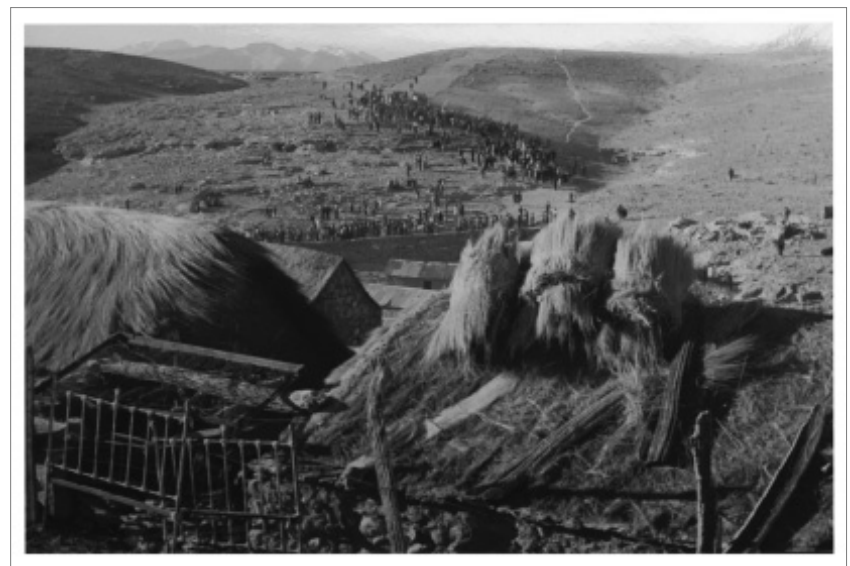

7. Conchi Viejo, Región de Antofagasta, Chile. Roberto M. Gerstmann. Ca. 1940. Archivo Roberto Gerstmann, Biblioteca Universidad Católica del Norte, Antofagasta. 


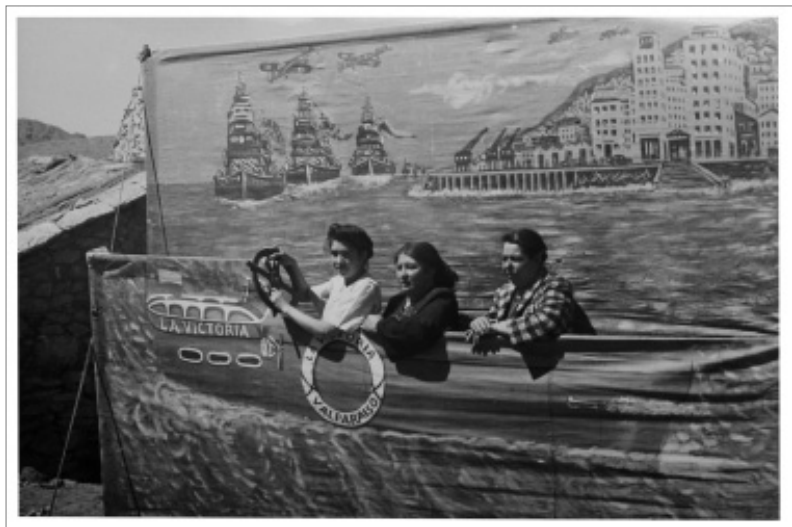

8. Conchi Viejo, Región de Antofagasta, Chile. Roberto M. Gerstmann. Ca. 1940. Archivo Roberto Gerstmann, Biblioteca Universidad Católica del Norte, Antofagasta.

Los sujetos andinos inmersos en estas ritualidades se nos presentan rígidos, sin movimiento, detenidos antes del acto fotográfico, inmutables frente a la cámara. Este procedimiento de la pose, junto con los dispositivos visuales propios de la fotografía del siglo XIX, se combinan con un foco parejo y una profundidad de campo no selectiva, propios de la fotografía documental en estos contextos, develando una estética que se construye en la conjunción de estas dos modalidades de producción fotográfica.

Contrariadamente, Antonio Quintana construye una estética fotográfica dinámica y cargada de movimiento, intentando una cobertura amplia de un tema específico dentro de la festividad, como por ejemplo los bailes religiosos o la procesión con la imagen de la Virgen del Carmen por las calles del pueblo (lámina 9). Estos aspectos de la celebración y del gesto ritual requieren destrezas específicas por parte del fotógrafo, que se manifiestan en el uso de tomas en picado, compuestos en planos generales con una mayor cobertura visual, que abarcan, por ejemplo, las aglomeraciones en torno a la imagen de la patrona (lámina 10).

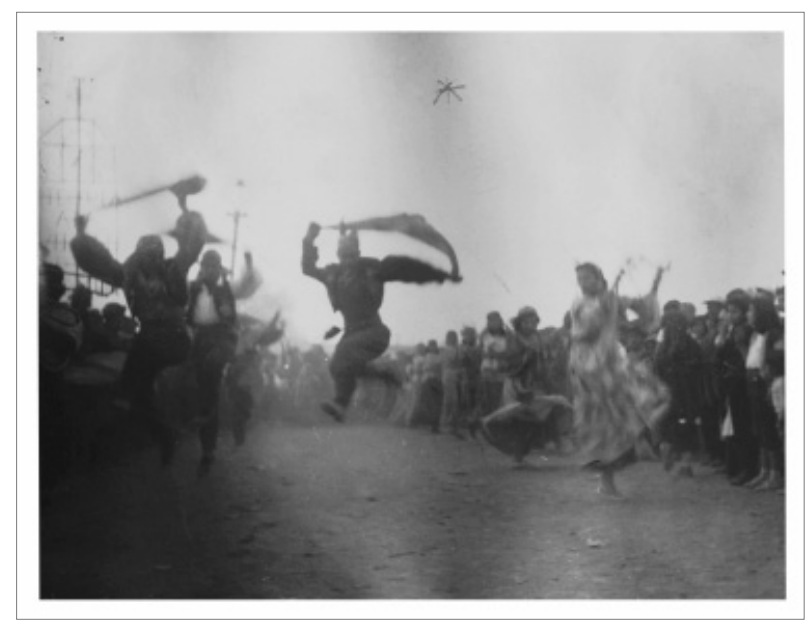

9. La Tirana, Comuna de Pozo Almonte, Región de Tarapacá, Chile. Antonio Quintana. Ca. 1958. Unidad de Fotografía, Archivo Central Andrés Bello, Universidad de Chile, Santiago. 


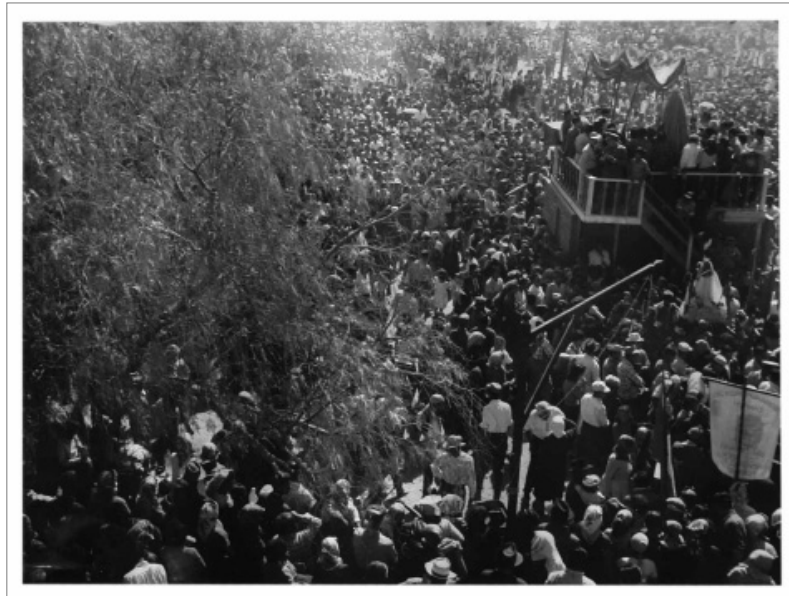

10. La Tirana, Comuna de Pozo Almonte, Región de Tarapacá, Chile. Antonio Quintana. Ca. 1958. Unidad de Fotografía, Archivo Central Andrés Bello, Universidad de Chile, Santiago.

Este fotógrafo se concentra en estas modalidades de producción fotográfica desde la perspectiva del espectador y registra lo que ve, evitando la búsqueda de composiciones, encuadres y planos fotográficos como lo hace Gerstmann, lo que implica la captura de la acción y el movimiento de los fotografiados. En este sentido, su trabajo es más improvisado, no se encuentra una pose como procedimiento visual, porque es el fotógrafo quien se mueve hacia el retratado, siguiendo en medio de la festividad, aquello que desea registrar. Esto se puede apreciar claramente en sus tiras de contacto, donde han quedado como secuencias, sus recorridos como fotógrafo. Para el evento de los bailes religiosos sus modalidades de representación tienen aún más movimiento, ya que se puede apreciar cómo Quintana se mueve con su cámara siguiendo a los danzantes, desde arriba en picado, desde abajo en contra-picado, cerrando los planos para tomas de retratos que destacan máscaras y trajes, y abriendo los planos para fotografiar el ambiente y la concurrencia (lámina 11).

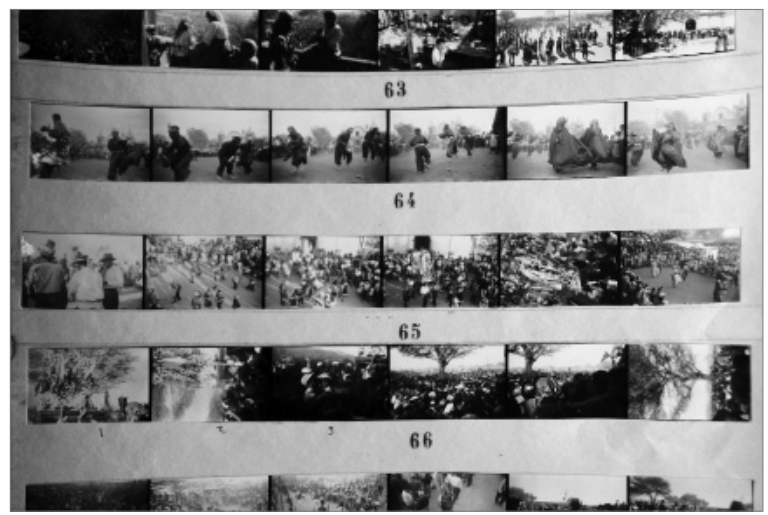

11. Contactos fotográficos, La Tirana, Comuna de Pozo Almonte, Región de Tarapacá, Chile. Antonio Quintana. Ca. 1958. Unidad de Fotografía, Archivo Central Andrés Bello, Universidad de Chile, Santiago. 
Los primeros planos siempre los asocia con un fondo pertinente, no siempre a foco, que no aísla al sujeto ni lo encierra en un encuadre limitado, permitiendo que la composición haga posible visualizar el entorno como un dato documental, más allá de los índices étnicos que presenten los personajes (lámina 12).

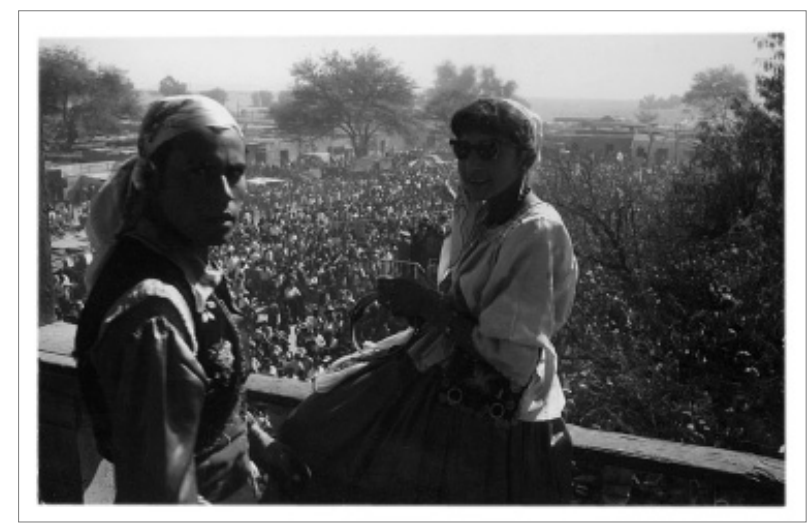

12. La Tirana, Comuna de Pozo Almonte, Región de Tarapacá, Chile. Antonio Quintana. Ca. 1958. Archivo Fotográfico y Digital, Biblioteca Nacional, Santiago.

Si consideramos que fotográficamente, una cobertura documental supone que la mirada del realizador se aplica desde distintos ángulos, planos y puntos de vista, estas imágenes de Gerstmann y Quintana tomadas durante la realización de estas fiestas en homenaje a la Virgen del Carmen, patrona de nuestro país, pueden ser adscritas indiscutiblemente a estas modalidades de representación. Como hemos visto en este análisis comparativo, las entradas posibles van desde una perspectiva visual que transcurre de lo general a lo particular, con una planificación lineal, según el orden de los acontecimientos que van sucediéndose dentro del contexto temporal de estos eventos rituales del norte de Chile. Se puede apreciar cómo el trabajo documental de Gerstmann está conformado por un número determinado de imágenes que resumen de manera significativa el sentido del suceso registrado. Contrariamente, en Quintana presenta un corpus mucho más amplio de imágenes que aseguran una recepción directa y extensa de esta festividad religiosa.

La cantidad de imágenes que se realizan en un trabajo documental está relacionada con las posibilidades de visualización, lo que implica la ubicación de la cámara y por lo tanto del fotógrafo. En el caso de Conchi Viejo, considerando que es un pequeño pueblo de la zona de las Tierras Altas del Loa, con calles intrincada y una topografía singular, lo más probable es que Gerstmann, precisamente, fuera demasiado «visible» como fotógrafo en medio de la fiesta — sobre todo en los años de la década de 1950 - y esto dificultara o limitara las posibilidades de visualizar y registrar los distintos momentos de la fiesta. Por el contrario, en La Tirana, la masividad de un evento como éste, más lo regular del terreno y del pueblo, permitieron al fotógrafo moverse sin dificultades, confundiéndose con los promesantes y el público, como lo muestran sus imágenes.

Por último, una cobertura de un suceso, fiesta o evento en general y su consecuente relato visual, se determina en un proceso de edición del material fotográfico, realizada 
por el propio autor de las imágenes o por un tercero. En el caso de Gerstmann, si bien él ordena su material numerando en cajas, tanto negativos como positivos, nunca dispuso en álbumes o soportes secundarios las imágenes de esta fiesta religiosa de Conchi Viejo, a diferencia de Quintana, cuyos materiales positivos en tira de prueba y diversos formatos, fueron compaginados - no sabemos si por el mismo o por terceros- en improvisados álbumes, con una clara intención de entregar un relato visual.

Si tenemos en cuenta diferencias y similitudes entre estos dos autores para este corpus de imágenes que hemos denominado "paisaje social y festividad ritual», el trabajo visual realizado resulta complementario. Así, ambas coberturas documentales de estos eventos rituales, distantes en la geografía del norte de Chile, pero cercanos en cuanto a su motivación principal: honrar a la Virgen del Carmen, se integran en el trabajo de estos dos autores, aún bajo sus diferentes modalidades de representación. El eje y sustento de esta complementariedad es el sujeto andino como protagonista de una fotografía con un claro carácter y estética documental y social.

\section{ESTÉTICA, PAISAJE Y SUJETO ANDINO EN LA FOTOGRAFÍA DE GERSTMANN Y QUINTANA}

En este segundo corpus de imágenes que hemos nombrado como «sujeto dentro del paisaje», se incluyen aquellas fotografías que muestran diferentes habitantes del desierto, tierras altas y el altiplano, pero siempre en relación al paisaje y espacios de estos territorios.

Para muchos fotógrafos, Gerstmann y Quintana no son una excepción, la inmensidad del paisaje del norte de Chile está asociada a una escasa población indígena y a una precariedad de recursos básicos en cuanto a la sobrevivencia. Bajo estas maneras de percibir el espacio y el habitante del desierto, tierras altas y el altiplano chileno, la presencia humana resulta invisibilizada en medio del paisaje natural o domesticado, lo cual se ve acentuado por los tonos de la fotografía en blanco y negro, que materializan una topografía y una configuración de estos territorios en una gama de grises muchas veces difícil de descomponer. Por lo tanto es la "figura» la principal seña y evidencia visual de una presencia humana que aparece dispuesta, a veces posando frente al lente, en encuadres de planos generales y panorámicos. En la identificación de los dispositivos y procedimientos visuales que aplica el fotógrafo para esta modalidad, la representación del indígena deja ver cómo el fotógrafo asimila esta presencia a otros elementos que ayudan a identificar al sujeto andino, pero que muchas veces adquieren o presentan un protagonismo mayor al propio sujeto retratado. Esta modalidad de producción fotográfica documenta esta puesta en escena, permitiéndonos constatar a través de la relación paisaje/presencia humana, la manera cómo ambos sujetos se interrelacionan dentro de la imagen fotográfica.

Al comparar este corpus del «sujeto dentro del paisaje» de Gerstmann y Quintana, se pueden establecer similitudes y diferencias importantes en los puntos de vista, encuadres, motivos, planos y foco, a diferencia del corpus "paisaje social y festividad ritual», en que ambos podían integrarse para constituir un conjunto único con características de continuidad. Las distancias que la cámara mantiene y que determinan encuadres, foco y plano respecto del sujeto, son parecidas en ambos corpus, donde los dos autores utilizan 
significativamente la perspectiva como distancia para abarcar una mayor cobertura sin definir un primer plano. En este sentido, la importancia de los elementos contenidos en el encuadre tiene el mismo valor, incluyendo el sujeto andino retratado.

Así, podemos ver cómo Gerstmann se sitúa en medio del encuadre instalando el punto de vista de la cámara frente a su infinito que se pierde frente a él, en un foco suficiente para ver los márgenes del pueblo de San Pedro de Atacama. El desierto al fondo se constituye en el punto central de la imagen, la presencia humana es un dato más que escenifica los costados de la composición fotográfica junto con árboles y casas (lámina 13). Quintana se ubica frente de una anciana centrándola como figura solitaria dentro del encuadre, atravesado en diagonal por un delgado curso artificial de agua, dejándola en la orilla superior, marcando el antes y el después de un camino paralelo construido visualmente con un punto de fuga que se proyecta hacia el costado superior de la imagen (lámina 14).

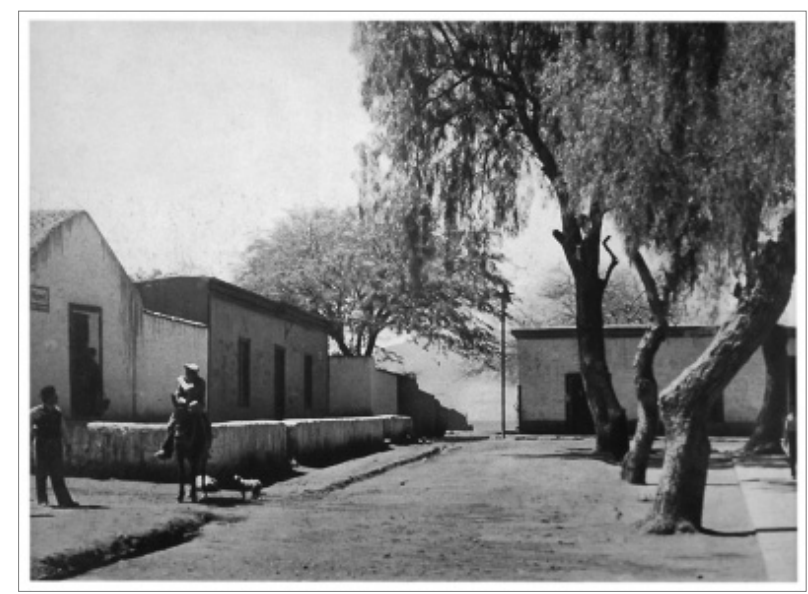

13. San Pedro de Atacama. Región de Antofagasta, Chile. Ca. 1950. Roberto M. Gerstmann. Publicada en Chile en 235 Cuadros. Gerstmann, 1959.

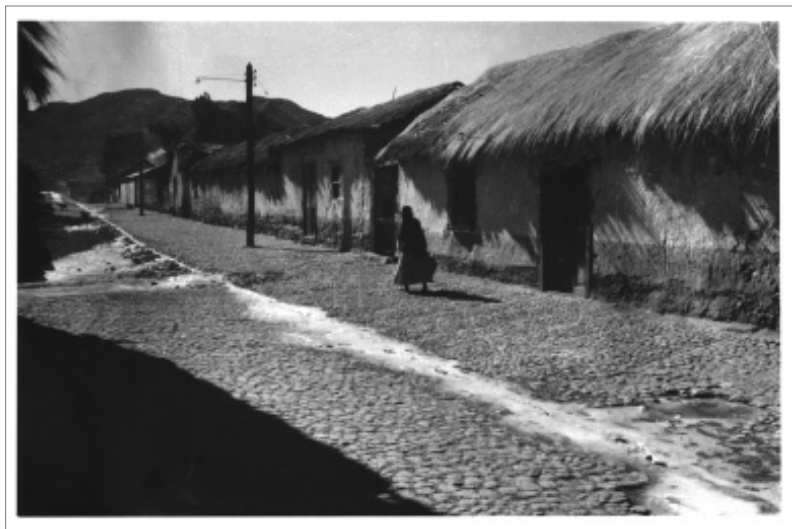

14. Pueblo de la zona de las Tierras Altas. Región de Antofagasta, Chile. Antonio Quintana. Ca. 1958. Unidad de Fotografía, Archivo Central Andrés Bello, Universidad de Chile, Santiago 
En otros ejemplos se aprecian dos tomas en picado desde los márgenes de dos pueblos diferentes, posición que es posible porque muchos de estos lugares del norte se emplazan en las quebradas que limitan pequeños valles fértiles. Una representa los momentos previos al desarrollo de una festividad religiosa, a la cual van llegando los vecinos; la otra, una escena cotidiana, más íntima, propia del acontecer diario, tomada por detrás de lo que podría definirse como un patio (láminas 15 y 16). Con un plano general y un foco a fondo, las dos imágenes resultan las espaldas de unos, los frentes de otros; algo así como el derecho y el revés de este paisaje domesticado del norte de nuestro país. Gerstmann es uno más de los visitantes que viene llegando, Quintana los enfrenta y los toma por sorpresa. Ambos fotógrafos eligen su posición de acuerdo a la oportunidad de representar, en el caso de Gerstmann lo público con la fiesta que trasgrede lo cotidiano, en el de Quintana, lo privado con los rigores de la vida en estos lejanos lugares. Los primeros planos no son sus objetivos, sino los referentes visuales que le dan la perspectiva a la imagen y al total de la escena y su contexto. Así, vemos como ambos, utilizando los mismos dispositivos visuales materializan modalidades de producción fotográfica con resultados opuestos en sus significaciones dentro del acto fotográfico.

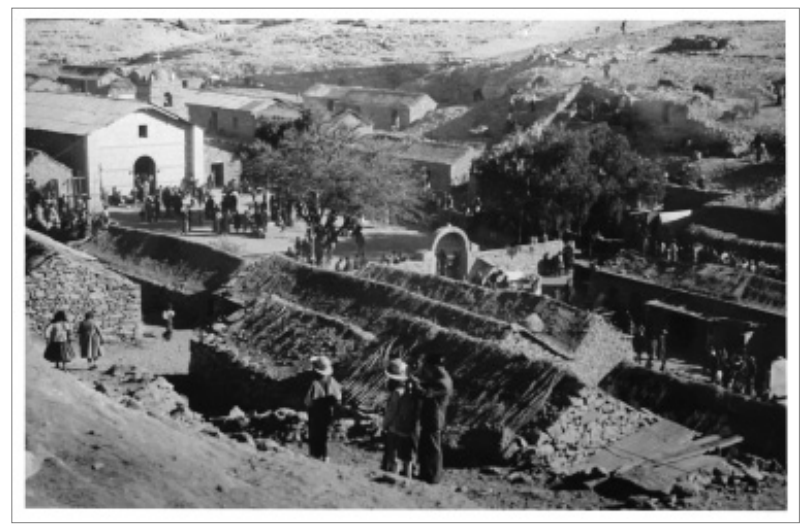

15. Pueblo de la zona de las Tierras Altas. Región de Antofagasta, Chile. Ca. 1950. Roberto M. Gerstmann. Archivo Roberto Gerstmann, Biblioteca Universidad Católica del Norte, Antofagasta.

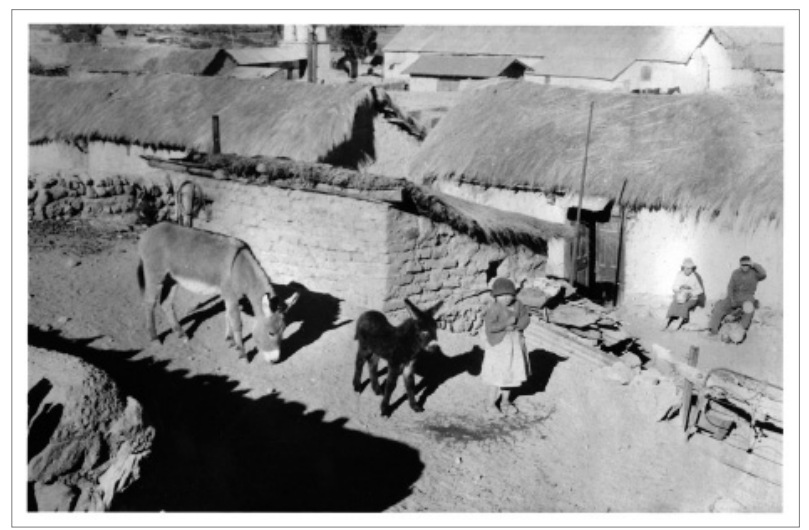

16. Pueblo de la zona de las Tierras Altas. Región de Antofagasta, Chile. Antonio Quintana. Ca. 1958. Unidad de Fotografía, Archivo Central Andrés Bello, Universidad de Chile, Santiago 
En un último caso mencionaremos dos imágenes donde el sujeto andino aparece fotografiado intencionalmente, posicionado en un primer plano dentro de un plano general, donde se aprecian escenas cotidianas en las cuales los sujetos presentan situaciones de visibilidad diferentes. Así, en este plano general se incluye la presencia de un sujeto andino, pero como un elemento de la composición fotográfica más que en su individualidad étnica y social (ver fotografías 17 y 18). Gerstmann se dispone visualmente frente a una escena que contiene todos los elementos necesarios para dirigir la mirada a una generalidad contextual en que todas las partes visibles se distribuyen en un mismo valor compositivo, incluido el fondo. Sin embargo, una mirada atenta descubre, y casi se sorprende, con la presencia de dos habitantes andinos sostenida en un precario equilibrio, una en el marco de una puerta y la otra aislada en un cuasi "fuera de cuadro", marginada en sombra a un vértice de la fotografía, ambas invisibilizadas por la placidez de la escena y la suma visual de elementos que la constituyen. La imagen que Quintana registra muestra un escenario mucho más simple, la escena se topa con un fondo de fachada de una casa y las dos presencias se encuentran en una redundancia de miradas. La mirada del fotógrafo y la mirada de la muchacha coinciden sobre el sujeto que ocupa el centro de la composición, pero minimizado por la distancia. Podríamos definir esta imagen como un resumen que comprime e indica, severamente, cada uno de los elementos que representan lo básico del quehacer cotidiano en un pueblo de la zona de las tierras altas, es decir, las actividades de pastoreo, la presencia del agua como un bien preciado que trae la vida, las construcciones propias de la región, todo esto inmerso en una atmósfera de sol y luz, muy propia del norte de Chile.

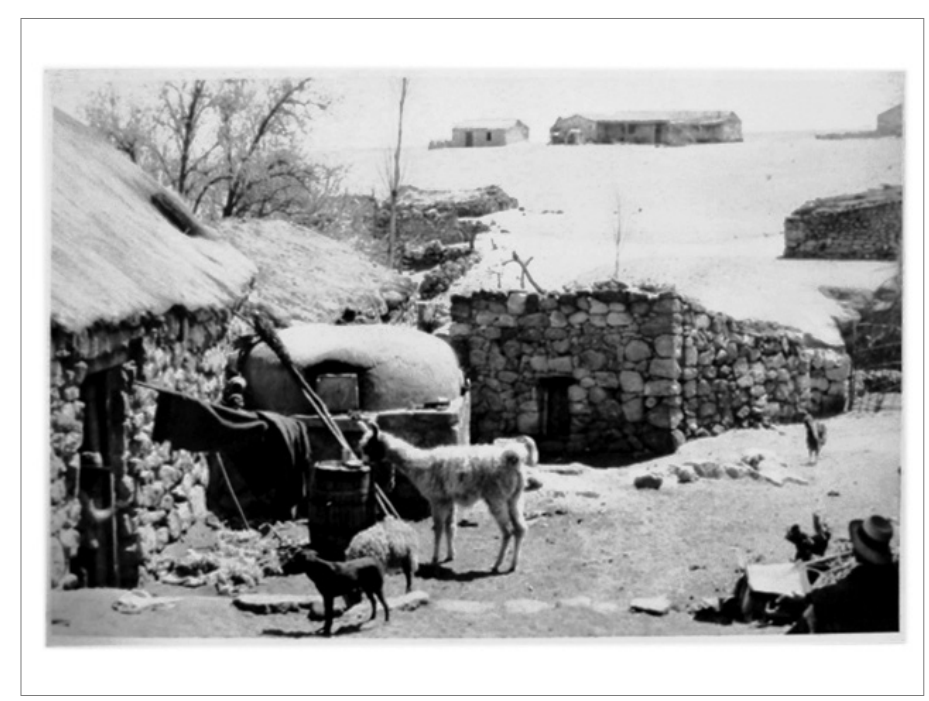

17. Toconao, Región de Antofagasta. Ca. 1950. Roberto M. Gerstmann. Archivo Roberto Gerstmann, Biblioteca Universidad Católica del Norte, Antofagasta. 


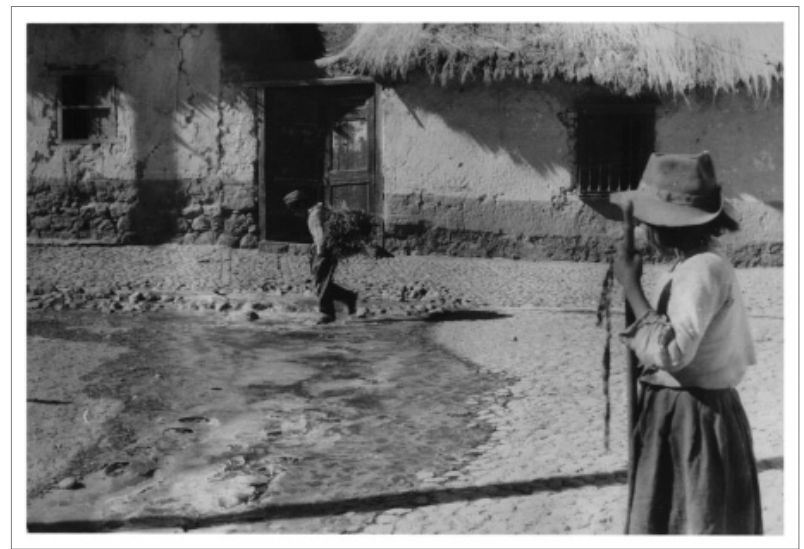

18. Pueblo de la zona de las Tierras Altas. Región de Antofagasta, Chile. Antonio Quintana. Ca. 1958. Unidad de

Fotografía, Archivo Central Andrés Bello, Universidad de Chile, Santiago

Como hemos visto en este corpus las modalidades de producción fotográfica presentan un sujeto formando parte de un espacio y un territorio en sus actividades cotidianas y rituales. El paisaje se constituye así en un contenedor de un sujeto que aparece marginado, invisibilizado, técnica y naturalmente por el uso de determinados dispositivos y procedimientos visuales. De esta forma, la presencia de este sujeto se percibe, más que por su peso visual dentro de la composición fotográfica, por la puesta en escena de aquellos elementos que hacen referencia a lo andino, como un espacio de quebradas, animales como camélidos y burros y una arquitectura de piedra y adobe. En sus diferencias y similitudes, cada uno de estos autores construye una estética particular de los indígenas del Norte Grande.

\section{ESTÉTICA Y PAISAJE ANDINO EN LA FOTOGRAFÍA DE GERSTMANN Y QUINTANA}

En este tercer corpus analizaremos aquellas fotografías que hemos definido como "paisaje sin sujeto». Las representaciones del paisaje del Norte Grande, ya sea natural, es decir aquel espacio territorial y geográfico que no presenta la intervención del hombre, o domesticado, definido como aquel espacio modificado por la mano del hombre, se enmarcan en la experiencia visual de exteriores amplios y abiertos, con una geografía de horizontes extensos y en ocasiones, contenida en estrechas quebradas y pequeños valles, con una presencia humana que muchas es difícil de descubrir. Rastros y huellas de la propia transformación que el paisaje andino experimenta natural y artificialmente, refieren tanto a una cambio geológico como a una conquista, a un proceso de domesticación y ocupación de espacios y pisos ecológicos, un constante habitar que transita de la ocupación al abandono, que ha quedado materializado en ruinas y vestigios arqueológicos.

Bajo estas condiciones geográficas y topográficas, el paisaje del desierto y el altiplano se visualiza y configura desde distancias que fotográficamente y de acuerdo a los dispositivos visuales ya mencionados se constituyen de manera generalizante. Bajo estas miradas y 
composiciones abarcadoras, los puntos de referencia visuales y las proporciones son procedimientos obligados para dar a conocer la realidad de un paisaje que se dibuja en trazos, trozos y tonos, con pocos elementos y detalles diferenciadores, casi de aspecto minimalista.

La representación del paisaje andino en nuestros dos autores fotógrafos se sostiene, precisamente, en estos puntos de referencias y proporciones. En el corpus fotográfico de "paisaje sin sujeto", Gerstmann se concentra en las cualidades formales del territorio andino, recuperando la geomorfología del desierto y mostrando su extensión, minimizando la ocupación y la presencia humana (lámina 19). Sus referencias frente a esta amplitud son presentadas con el posicionamiento en primerísimos planos de elementos que forman parte de este paisaje, como rocas o plantas. Su propia posición frente a estos, asegura la visión y organización de las proporciones, el espectador rápidamente percibe las distancias inalcanzables del paisaje, expuestas en los planos panorámicos (ver fotografía 20). Así vemos la manera cómo Gerstmann entra en detalles, una vez que ha abarcado fotográfica y estéticamente la totalidad, describiendo el emplazamiento de estos detalles y su inserción en el paisaje (lámina 21).

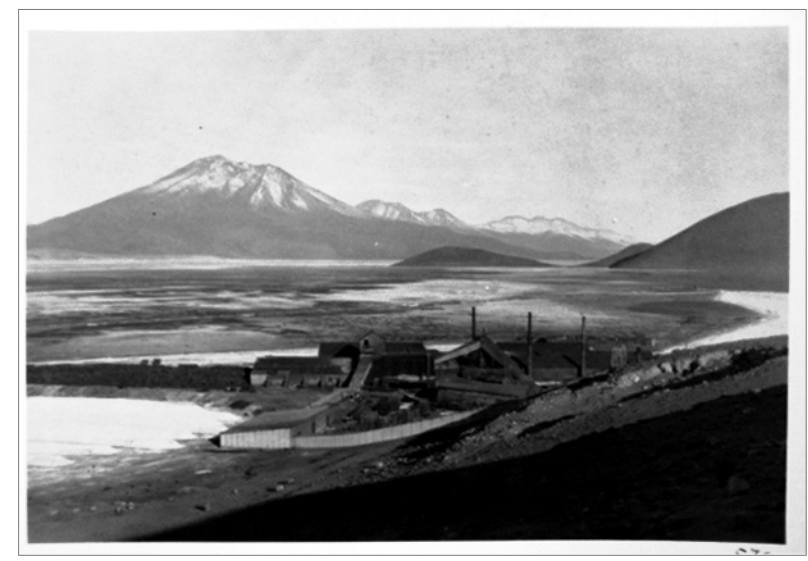

19. Salar de Ascotán, Región de Antofagasta, Chile. Ca. 1950. Roberto M. Gerstmann. Museo Histórico Nacional, Santiago.

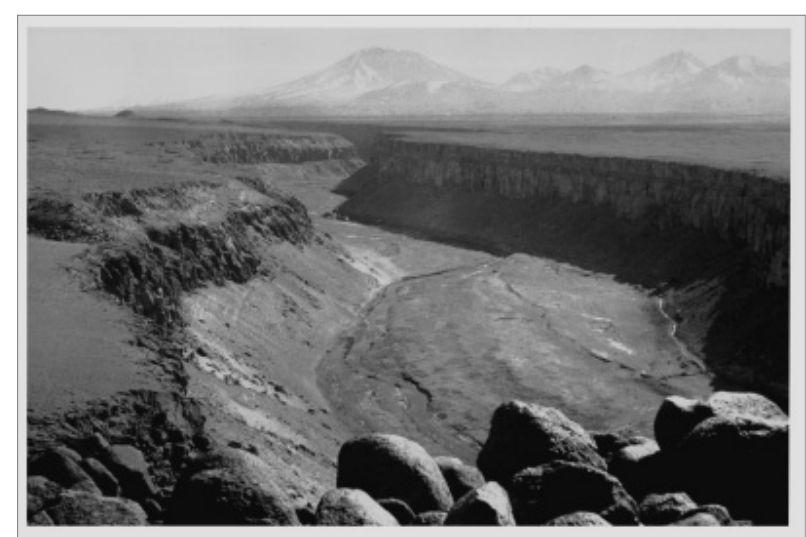

20. Cañón del río Loa, Región de Antofagasta, Chile. Ca. 1950. Roberto M. Gerstmann Museo Histórico Nacional, Santiago. 
Quintana se concentra precisamente en los vestigios y el rastro de una presencia humana pasada, pero también registra arquitectura, calles y algunos detalles de pueblos vigentes, sobre todo de las zonas altiplánica y también de las tierras altas, pero donde no deja de manifestarse una ausencia del sujeto andino. De esta forma, el paisaje se transforma en el hilo conductor inevitable desde un habitar abandonado, poblado en épocas anteriores -incluso prehispánicas - pero ahora muerto y ruinoso, hacia un habitar actual sin embargo, casi despoblado, donde la existencia humana está fotográficamente invisibilizada (lámina 22). Como autor-observador de estos paisajes, se ubica hacia el interior de sus puntos de referencia, desde allí realiza el reconocimiento, centrando en su encuadre su objeto, totalmente consciente de las proporciones de lo que está fotografiando (lámina 23). Su particular manera de desplegar su mirada sobre este paisaje, en cierta forma, valida una estética que se sustenta en las huellas o vestigios de un pasado y en la soledad y ausencias humanas de la actualidad.

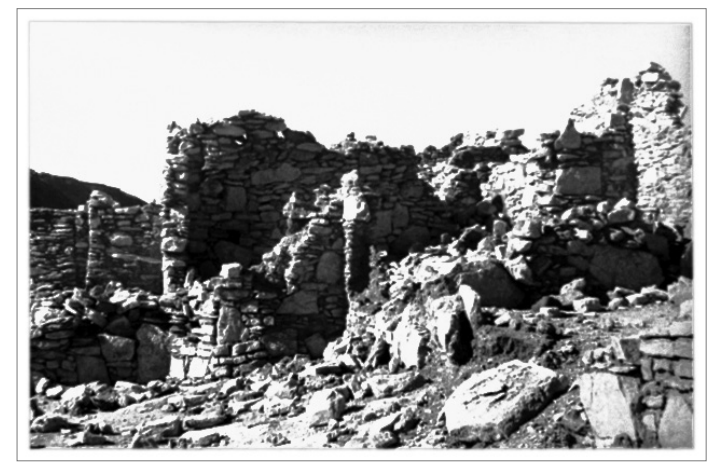

21. Pucará de Lasana, Región de Antofagasta, Chile. Ca. 1950. Roberto M. Gerstmann. Museo Histórico Nacional, Santiago.

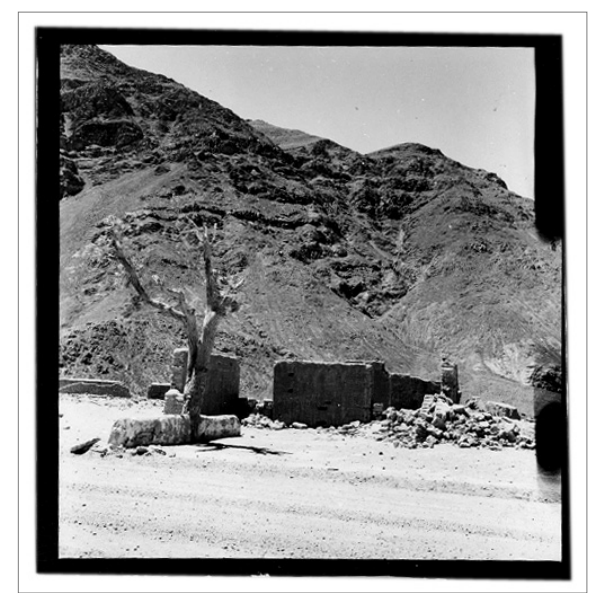

Fotografía 22. Ruinas de la zona del desierto de Atacama, Chile. Ca. 1958. Antonio Quintana. Archivo Fotográfico y Digital, Biblioteca Nacional, Santiago 


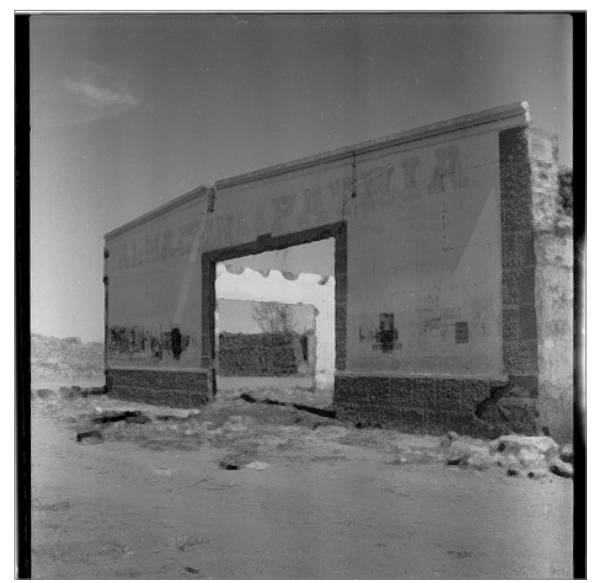

23. Ruinas de la zona del desierto de Atacama. Ca. 1958. Antonio Quintana. Archivo Fotográfico y Digital, Biblioteca Nacional, Santiago.

Es probable que por estas particularidades estéticas no sintamos el impulso de habitar este paisaje y así nuestros imaginarios visuales y colectivos de lo andino, se van constituyendo de acuerdo a la ausencia de lo humano, expresado en una invisibilización fotográfica del indígena del Norte Grande. Por otra parte, cuando la presencia humana se manifiesta visualmente en estos territorio, deviene en ruina y abandono, ya que se muestra a través de la imagen de sitios arqueológicos con vestigios de construcciones o pueblos y oficinas de las época de la explotación del salitrera de comienzos del siglo XX, impregnando al paisaje domesticado de una áurea fantasmal e inhabitada. Bajo estas dos modalidades de producción fotográfica se manifiesta una dialéctica donde el pasado y el presente se materializan en un dentro y fuera de la condición de territorio habitado. El paisaje se constituye así en el protagonista, sujeto de lo fotográfico.

\section{GERSTMANN Y QUINTANA DOS MIRADAS SOBRE LOS INDÍGENAS DEL NORTE GRANDE}

A través de la fotografía podemos también participar en nuevas experiencias del espacio [...] con su ayuda hemos logrado un engrandecimiento y una sublimación de nuestro concepto del espacio: la aprehensión de una nueva cultura espacial. Gracias al fotógrafo, la humanidad ha adquirido la capacidad de percibir sus alrededores y su propia existencia con nuevos ojos.

Lásló Moholy - Nagy

Vistos y analizados los ejemplos de los tres corpus definidos, podemos plantear una concatenación de hechos fotográficos, acontecimientos donde intervienen el dominio, la estrategia, la significación y la finalidad, dados por la presencia del fotógrafo al encuen- 
tro de un territorio consignado como naturalmente bello, históricamente conflictivo y humanamente difícil.

Estas imágenes fotográficas del desierto, las tierras altas y el altiplano andino pueden, por lo mismo, adscribirse visualmente a cada una de estas condiciones o a una combinatoria de las mismas, cargando de significaciones la mirada del fotógrafo, en este caso, de dos autores que se aproximan a su sujeto desde diferentes perspectivas visuales, sea esta estética y/o documental, donde concentran su interés y aplican dispositivos y procedimientos visuales con distinta intensidad. A pesar de las diferencias analizadas en el uso de estos dispositivos y procedimientos, su aplicación refiere más bien a una complementación visual de ambos autores, donde lo documental, situado en un mismo espacio y tiempo, se da por condición intrínseca del acto fotográfico.

Si bien los escenarios definidos para este análisis son representados de acuerdo a las diversas modalidades de producción fotográficas descritas, la visión conjunta de estos fotógrafos complementan y resumen un imaginario instalado, en que paisaje y sujeto andino son indisolubles, aunque reemplazables, e incluso confundidos.

Roberto Gerstmann y Antonio Quintana, más allá de fotografiar desde dos posiciones contrarias, registran un sujeto que ambos describen de manera complementaria presente o no en la imagen fotográfica. Si Quintana va a los hechos, Gerstmann los describe, si Quintana va al detalle, Gerstmann los detalla al contextualizarlos.

La mirada de estos dos fotógrafos sobre los indígenas del Norte Grande nos ha permitido, como observadores distraídos por la sobreproducción de imágenes del siglo XXI, percibir nuestros propios alrededores de nuestra propia existencia, con "nuevos ojos", para participar en nuevas experiencias sobre los territorios del desierto y el altiplano chileno.

\section{REFERENCIAS}

Alvarado, Margarita; Pedro Mege, Christian Báez. (eds.). (2001). Mapuche. Fotografías Siglos XIX y XX. Construcción y montaje de un imaginario. Santiago: Pehuén Editores.

Alvarado, Margarita; Mariana Matthews, Carla Möller. (eds.). (2009). Roberto Gerstmann. Fotografías, paisajes y territorios latinoamericanos. Santiago: Pehuén Editores.

Batchen, Geoffrey. (2004). Arder en deseos. La concepción de la fotografía. Barcelona: Gustavo Gili.

Brisset, Demetrio. (1999). Acerca de la fotografía etnográfcia. Obtenido el 10 de septiembre desde <http://www.ugr.es/ pwlac/>.

Burgin, Víctor. (2004). Ensayos. Barcelona: Gustavo Gili.

Cordero, Jaime. (2001). Cinematos Grafías. Santiago: Colección teoría, Universidad de Chile.

De la Nuez, Iván. (2003-2004). El otro rostro de Che. La imagen latinoamericana para el siglo XXI. En Alejandro Castellote (ed.). Mapas abiertos. Fotografía Latinoamericana 1991-2002. Barcelona: Lunwerg Editores. 
Dubois, Philippe. (1986). El acto fotográfico. De la representación a la recepción. Barcelona: Paidós.

Fiore, Danae. (2007). Arqueología con fotografías: El registro fotográfico en la investigación arqueológica y el caso de Tierra del Fuego. En Flavia Morello, Mateo Martinic, Alfredo Prieto y Gabriel Bahamonde (eds.), Arqueología de Fuego-Patagonia. Levantando piedras, desenterrando huesos... y develando arcanos (pp. 767-778). Punta Arenas. Ediciones CEQUIA.

Gerstmann, Roberto. (1928). Bolivia: 150 grabados en cobre. París: Braun y Cía. Editores.

-. (1932). Chile: 280 grabados en cobre. París: Braun y Cía. Editores.

-. (1951). Colombia: 200 grabados en cobre. París: Braun y Cía. Editores.

-. (1959). Chile en 235 cuadros. Düsseldorf: Hub. Hoch-Düsseldorf Verlag.

Giordano, Mariana. (2005). Discursos e imagen sobre el indígena chaqueño. La Plata: Ediciones al Margen.

Maturana, Felipe. (2007). Fotografía fueguina y antropología regional (1895 - 1931). Una mirada desde la antropología visual. En Margarita Alvarado, Carolina Odone, Felipe Maturana y Dánae Fiore (eds.), Fueguinos. Fotografías siglo XIX y XX. Imágenes e imaginarios del fin del mundo (pp. 49-60). Santiago: Pehuén Editores.

Masotta, Carlos. (2007). Indios en las primeras postales fotográficas argentinas del s. $X X$. Buenos Aires: La Marca.

Moholy-Nagy, László. Del pigmento a la luz (1936). En. Joan Foncuberta (ed.), Estética fotográfica. Una selección de textos (pp. 185-197). Barcelona: Editorial Gustavo Gili.

Moreno, José; Denise Fresard. (2006). Fotografía. Antonio Quintana, 1904-1972. Santiago: Pehuén Editores.

Poole, Devorah. (2000). Visión, raza y modernidad. Una economía visual del mundo andino de imágenes. Lima: Ediciones Sur.

Sontag, Susan. (1981). Sobre la fotografía. Barcelona: Edhasa.

Szarkowski, John. (1966). The Photographer's Eye. Nueva York: Catálogo Museo de Arte Moderno.

-. (1989). Photography Until Now. Nueva York: Catálogo Museo de Arte Moderno.

Tagg, John. (1988). El peso de la representación. Barcelona: Gustavo Gili.

Tausk, Petr. (1978). Historia de la Fotografía en el siglo XX. Barcelona: Gustavo Gili.

Recepción: mayo 2009

Aceptación: julio 2009 